\title{
Integrating Social Responsibility Into Business School Undergraduate Education: A Student Perspective
}

Nelson A. Barber, University of New Hampshire, USA

Venky Venkatachalam, University of New Hampshire, USA

\begin{abstract}
Organizations and society at large recognize that ethically and socially responsible behavior plays a crucial role in good business practices. Debate about social responsibility centers on the responsibilities of consumers and businesses working towards a sustainable future with a new focus on business education. This realization has led employers to expect and demand that business schools facilitate the training of students in social responsibility. To accomplish this, key components to consider within undergraduate business school programs are the development of curriculum, pedagogy, and delivery methods best practices. The end result of this effort would be graduates possessing a range of perspectives and competences that increase their awareness of good socially responsible business practices. Yet, how best to develop the programs, curriculum, and pedagogy that deliver socially responsible business practices to students is still undecided. Equally important is to understand who these "students" are and what they want from business education programs.
\end{abstract}

To develop a meaningful curriculum model, students from across a large northeast university campus were assessed on their perspectives of socially responsible business programs, curriculum, and pedagogy practices. The results suggest significant differences between the student groups in their interest in social responsible business practices and the importance of environmental issues and topics in the curriculum.

Keywords: Pedagogy; Curriculum; Social Responsible Business Education; Undergraduate

\section{INTRODUCTION}

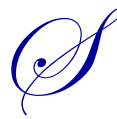

ocial responsibility has been debated for decades (IISD, 2004; Luchs \& Mooradian, 2002) and is generally defined as the 'duty every organization or individual has to perform to maintain a balance between society, the economy and the environment.' Research on corporate socially responsible (CSR) business practices has been receiving increasing attention through research (Karna et al., 2001; Singhapakdi et al., 2001; Maignan et al., 2005), advertising, and media coverage that promotes socially responsible business practices. Businesses are confronted with increasing demands from numerous stakeholders concerning the environmental performance of their products (Pesonen, 2003), such as increasing environmental regulation and demands from consumers. Consumers in particular are asking for socially responsible products, governments place increasing demands on companies' environmental performance, employees are anxious about the health and safety facets of production, and nongovernmental organizations are running campaigns for socially responsible behaviors (Barber, Deale \& Goodman, 2011). There is an increasing awareness of the need for corporate accountability and creating entrepreneurial solutions to the world's challenges for socially responsible behavior. To this point, Blundel, Spence and Zerbinati (2010) suggested that "Entrepreneurial Social Responsibility is the dynamic consideration of, and response to, issues beyond the narrow economic, technical and legal requirements of the firm to accomplish social and environmental benefits along with the traditional economic gains sought in the entrepreneurial process" (p.125). 
Social responsibility has become a competitive issue in higher education (Savitz \& Weber, 2007; Aber, Kelly \& Malroy, 2009), as evidenced by the Association for the Advancement of Sustainability in Higher Education (AASHE, 2012) which has 874 members across the globe representing higher education, business, government, and non-profits. Increasingly undergraduate and graduate programs, schools, and non-credit certificate programs focused on sustainability are establishing themselves across the U.S. to meet the growing demands of students and industry. Social responsibility, in terms of the environment impact, has been incorporated into numerous degree programs, such as in engineering (Fien, 2002), computer and literature courses (Down, 2006), architecture (Wright, 2003), and tourism (Swanger, Benson \& Paxson, Tesone, 2004; Aber, et al., 2009; Barber et al., 2011).

Even business schools have begun implementing socially responsible initiatives with the goal of educating future leaders, managers, and workers who will ultimately struggle with environmental, social, and economic systems throughout their careers (Deale et al., 2009; Elkington, 1998; Savitz \& Weber, 2006; Stubbs \& Schapper, 2011).

Despite these efforts, little is known individually about the three main stakeholders (students, educators, and the industry professionals that will be hiring the graduating students); each whose views should be considered as valuable input into the development of socially responsible business education programs. Several studies have looked at MBA programs, from a programmatic perspective (Christensen et al., 2007; Stubbs \& Schapper, 2011) and from the student perspective (Haski-Leventhal; 2012). Nicholsson \& DeMoss (2009) evaluated program directors views on ethics and social responsibility. However, undergraduate students appear to be overlooked.

But should the focus be only on business school undergraduates? Should there by an inter-disciplinary approach to teaching socially responsible business practices? The purpose of this study is to understand from undergraduate students' what they consider as the important aspects of social responsibility in business education from the programmatic, curricula, and pedagogical perspectives. The following sections will discuss corporate social responsibility, integration into business education, and the study hypotheses.

\section{LITERATURE REVIEW}

\section{Corporate Social Responsibility}

Anyone who keeps abreast of current affairs cannot help but be struck by the ongoing debates around social responsibility, including ethics, transparency, and accountability. Leaders in a range of small, medium, and large organizations (e.g. banks, insurance, manufacturing, hotels, and tourism destinations) are giving social responsibility serious consideration (Eber, 2002; Miller, 2005, p. 640; Deale, et al., 2009). For example, General Electric, HewlettPackard, and IBM have made social responsibility a priority. Hewlett-Packard has been working with their supply chain to increase suppliers' accountability to workers, communities, and the environment (Odell, 2008). The case for social responsibility in business is more than purely financial gains based on sound environmental practices but involves attracting and retaining high-caliber people. Bradbury (2003) suggested that a socially responsible enterprise drives creativity and therefore a resurgence of intrapreneurialism (an employee within an organization responsible for turning an idea into a profitable finished product). To external stakeholders, it offers image enhancement and encourages business to operate over the long term.

As a concept, corporate social responsibility is known by several names, such as social responsibility (SR), corporate citizenship, and, in the case of tourism, corporate sustainability. The Dow Jones Sustainability Index (2012) website defines corporate sustainability as: "Corporate sustainability is a business approach that creates long-term shareholder value by embracing opportunities and managing risks deriving from economic, environmental, and social developments. Corporate sustainability leaders achieve long-term shareholder value by gearing their strategies and management to harness the market's potential for sustainability products and services while, at the same time, successfully reducing and avoiding sustainability costs and risks."

Another definition of corporate social responsibility is provided in an association known as business in the community (BITC): “. . . the management of a company's positive impact on society and the environment through its operations, products, or services and through its interaction with key stakeholders, such as employees, customers, investors, and suppliers" (Business in the Community, 2005: Holcomb, Upchurch \& Okumus, 2007). 
The commonality among these definitions of corporate social responsibility is that companies should engage in socially responsible behavior as part of their organizational strategy. The outcome of embracing social responsibility as an organizational strategy is that it offers the organization a competitive advantage within the immediate marketplace (Porter \& Kramer, 2006). For instance, according to a report published by Business for Social Responsibility, 67 percent of executives strongly agree that implementation of CSR initiatives provide a competitive advantage for their organization (Business for Social Responsibility, 2006).

Managing corporate social responsibility is a required mindset not limited to just the financial function of an organization but should include all of the functions from product development, production management, engineering, human resources management, and communication, among others (Pesonen, 2003). Thus, business education at universities has an important role in training all future business leaders, managers, and workers by providing them with skills needed for the changing requirements concerning corporate social responsibility issues.

\section{Integrating Social Responsibility into Business Education}

With the focus on social responsibility in politics, science, business, and the media, it is certainly a serious topic that students need to understand and explore. As Moore (2005, p. 327) noted, "There is a need to envision what a 'sustainable' university might look like, including visions of sustainable education programs and sustainable education communities." The inclusion of social responsibility in the curriculum is not intended to push any 'politically correct' line, but rather to encourage students to engage in a conversation about this important issue. As discussed by Eber (2002), in addition to being valuable in its own right, a socially responsible approach to education is a comprehensive conversation that advances crucial transferable skills and behaviors, including analytical and critical thinking, managing information, arguing and communicating effectively, developing respect for the diversity of people, cultures and environments, and for social justice, equity and human rights, and fostering personal responsibility and citizenship.

Numerous papers concerned with teaching social responsible education in post-secondary institutions have been published in the International Journal of Sustainability in Higher Education (IJSHE) and Journal of Management Education focusing on how it has been included in curricula within academic areas and incorporated into university and college system operations (Alvarez \& Rogers, 2006; Bradbury, 2003; Down, 2006; Fien, 2002; Kevany, 2007; Lourdel et al., 2007; Moore, 2005; Posch \& Steiner, 2006). As Yencken and Wilkinson (2000) noted, numerous authors have centered their papers on specific economic, social, political, or ecological factors. The American Association of Sustainability in Higher Education (AASHE, 2009) observed that campuses frequently focus on efforts to implement environmental or carbon-footprint audits, reduce the use of energy, increase the use of waste and recycling systems, and engage in green purchasing policies. Also, the Association to Advance Collegiate Schools of Business (AACSB, 2012) has created a series of conferences and workshops directed at business schools which focuses on integration of social responsibility in their programs.

There is debate whether social responsibility should be integrated into existing courses, taught as standalone courses, or through new programs (Christensen et al., 2007; Rusinko, 2010). However, it is accomplished that the integration of socially responsible practices can be a complex and difficult process. Effectively integrating social responsibility in business education needs to be considered as to how it is implemented or delivered (e.g., Sammalisto \& Lindhqvist, 2008; Rusinko, 2010). From a programmatic perspective, social responsibility can be integrated through new structure, such as a major, minor, or program. From a curriculum perspective, social responsibility can be integrated through an existing structure, such as a course using a new topic like social responsible marketing concepts. Finally, social responsibility can be integrated from a pedagogical perspective using case studies or experiential learning (Christensen et al., 2007; Rusinko, 2010). Irrespective of the approach used, integrating social responsibility into the business curriculum needs to relate to specific management tasks, such as finance, organizational behavior, entrepreneurship, and strategic management, among others, so that students will be better prepared to put them into operation in the management of businesses (Jurowski \& Liburd, 2001; Rusinko, 2010).

Rusinko (2010) suggested, from the pedagogical view, the importance of curricular engagement to help students develop vital personal and leadership skills. Rusinko (2010) suggested a matrix (see Table 1) to aid faculty, 
staff, and administrators at the programmatic level in business education to determine and choose the best options to make more effective decisions about integrating social responsibility.

Table 1: Matrix to Integrate Social Responsibility in and Business Education

\begin{tabular}{|l|l|l|}
\hline \multirow{2}{*}{ Focus } & \multicolumn{1}{|c|}{ Delivery } \\
\cline { 2 - 3 } $\begin{array}{l}\text { Narrow (Discipline Specific) } \\
\text { Curricular }\end{array}$ & \multicolumn{1}{|c|}{ Existing Structures } & \multicolumn{1}{c|}{ New Structures } \\
\hline $\begin{array}{l}\text { Broad (Cross-Disciplinary) } \\
\text { Curricular }\end{array}$ & Integrating into existing course(s) & $\begin{array}{l}\text { Create new discipline-specific socially } \\
\text { responsible course(s) }\end{array}$ \\
\hline Adapted and extended from Rusinko (2010) & $\begin{array}{l}\text { Create new, cross-disciplinary socially } \\
\text { responsible course(s), Minor(s), program(s) }\end{array}$ \\
\hline
\end{tabular}

However, one of the key stakeholders in this discussion - undergraduate students - has been absent from the conversation and likely has valuable input (Barth \& Timm, 2010). Undergraduate Perspectives (Net Impact, 2010), suggest today's undergraduate students believe in the power of the capitalist system. Eighty-eight percent believe the for-profit sector should address social and environmental issues; however, only $37 \%$ believe corporations are working for the betterment of society. Interestingly, $74 \%$ of these same students envision themselves as a leader who will improve the world's problems, but $77 \%$ say that colleges and universities need to do a better job of helping train socially and environmentally responsible individuals.

\section{Study Purpose and Hypotheses}

As Roome (2005) stressed, there is a need to include multiple academic stakeholders (e.g. faculty and students from various disciplines) and stakeholders outside of the academic environment. However, as noted earlier, there was little work found that assessed undergraduate students. Therefore, using the concepts from Table 1, this study evaluated the perceived importance of socially responsible business education programs, curricula, and pedagogical methods by undergraduate students from multiple disciplines. It is our contention that it is not only the business students that need to better understand socially responsible business practices, but also those students from cross-disciplinary studies (e.g. engineering, chemistry, etc.) who would likely work in businesses and have an impact on how an organization views socially responsible business behavior. Because the literature is not replete with research on students' assessment in this area, no directional differences were hypothesized. The following research hypotheses have been proposed:

$\mathbf{H}_{\mathbf{1}}$ : There is a significant difference between students from different colleges as to their interest in social responsibility.

$\mathbf{H}_{2}$ : There is a significant difference between students from different colleges and their linking socially responsible issues and business practices in educational curricula.

$\mathbf{H}_{3}$ : There is a significant difference between students from different colleges and how they would prefer programs in social responsibility business education be offered.

$\mathbf{H}_{\mathbf{4}}$ : There is a significant difference between students from different colleges in the relevance they place socially responsible curricula topics.

H5: There is a significant difference between students from different colleges in the pedagogical approaches to teaching social responsibility in business programs.

\section{METHODS}

\section{Study Design and Sample Selection}

The population for this study was based on four colleges of a northeast public university - engineering and physical sciences, life sciences, liberal arts, and business. This university has an approximate enrollment (2012) of 13,000 students and these four colleges represent approximately $90 \%$ of the undergraduate student body. 
To collect data, a URL link and a brief description of the survey were e-mailed to students by each of the college deans or associate deans. Before data collection procedures began, the questionnaire was pilot-tested with students and educators at the University's business school to determine whether the instrument could be understood clearly by respondents and to ensure reliability of the instrument.

The questionnaire included five distinct sections. Likert scales and bi-polar questions were used with a four-point anchoring. A 4-point scale is used to produce a forced choice measure where no indifferent option is available demanding much more from respondents. The first section asked students about their current status (e.g. freshmen class), which college they were enrolled in (e.g. Engineering and Physical Sciences, Business, etc.), and their gender. For those in the business school, additional questions were asked about the program they were enrolled in (e.g. Accounting, Marketing, Hospitality Management, etc.). A full description of the remaining sections is provided in Table 2.

Table 2: Measurement Items

\begin{tabular}{|c|c|c|}
\hline Question & Statements & Assessment \\
\hline How interested are you in the following? ${ }^{1}$ & $\begin{array}{ll} & \text { Environmental sustainability } \\
\circ & \text { Human sustainability } \\
\circ & \text { Social sustainability } \\
\circ & \text { Economic sustainability }\end{array}$ & $\begin{array}{l}\text { Not very interested } \\
\text { Not interested } \\
\text { Interested } \\
\text { Very interested }\end{array}$ \\
\hline $\begin{array}{l}\text { Linking environmental issues and business practices } \\
\text { in educational curricula }{ }^{1}\end{array}$ & $\begin{array}{ll} & \text { Interesting but not really relevant. } \\
\circ & \text { We need to be aware of these issues. } \\
\circ & \text { We need to be thoroughly informed. } \\
\circ & \text { This is essential for business curriculum. } \\
\circ & \begin{array}{l}\text { Employers will look for this in my } \\
\text { educational background. }\end{array}\end{array}$ & $\begin{array}{l}\text { Strongly disagree } \\
\text { Disagree } \\
\text { Agree } \\
\text { Strongly agree }\end{array}$ \\
\hline $\begin{array}{l}\text { Rate each of these topics you see as being most or } \\
\text { least relevant to undergraduate offerings in } \\
\text { sustainable business education. }\end{array}$ & $\begin{array}{l}\text { A list of } 30 \text { items, ranging from energy conservation, } \\
\text { training and education, green marketing research, to } \\
\text { environmental auditing. }\end{array}$ & $\begin{array}{l}\text { Least relevant } \\
\text { Most relevant }\end{array}$ \\
\hline $\begin{array}{l}\text { How do you think sustainability concepts and } \\
\text { practices can best be learned? Check all that apply. }{ }^{1}\end{array}$ & $\begin{array}{l}\text { A list of } 14 \text { items, ranging from lecture, discussion, } \\
\text { field trip, to guest lecturer/speaker. }\end{array}$ & \\
\hline $\begin{array}{l}\text { How interested would you be in participating in one } \\
\text { or more of the following undergraduate offerings in } \\
\text { sustainable business? (Select all that apply) }\end{array}$ & $\begin{array}{ll}\circ & \text { Sustainable Business as an option } \\
\circ & \text { Sustainable Business as a minor } \\
\circ & \text { Elective courses in Sustainable Business }\end{array}$ & \\
\hline
\end{tabular}

\section{Data Analysis}

To obtain an overall representation of the sample, descriptive statistics, such as frequencies, means, and standard deviations, were employed. For hypotheses one and two, Analysis of Variance (ANOVA) was used to determine if statistically significant differences existed between the different colleges' cohorts with the Scheffé post hoc used for testing pairwise differences. For hypotheses three to five, Pearson's chi-square test was used to determine if there were significant differences between the reported proportions of the different college cohorts.

\section{RESULTS OF THE STUDY}

\section{Descriptive Statistics}

There were 639 total undergraduate responses; demographics are shown in Table 3. Sixty-percent were female, representing a larger proportion in both the colleges of business and life sciences and agriculture. With the exception of juniors (30\%), there was an equal representation of class levels. For hypothesis one, there is a significant difference between student groups from different colleges as to their interest in social responsibility. Overall, there were some significant differences $(p<.05)$ in the interest of social responsibility. For example, Life Sciences and Agriculture students were significantly more interested in human sustainability $(M=3.3)$ than the students in the colleges of business and engineering and physical sciences $(M=3.0$, respectively), $\mathrm{p}<.05$. 
Table 3: Respondent Demographics and Interest in Sustainability $(\mathrm{n}=639)$

\begin{tabular}{|c|c|c|c|c|c|}
\hline & Overall & $\begin{array}{c}\text { College of } \\
\text { Business }\end{array}$ & $\begin{array}{c}\text { College of } \\
\text { Engineering and } \\
\text { Physical Sciences }\end{array}$ & $\begin{array}{l}\text { College of Life } \\
\text { Sciences and } \\
\text { Agriculture }\end{array}$ & $\begin{array}{l}\text { College of } \\
\text { Liberal Arts }\end{array}$ \\
\hline \multicolumn{6}{|l|}{ Gender } \\
\hline Male & $257(40 \%)$ & $96(15 \%)$ & $73(11 \%)$ & $44(7 \%)$ & $44(7 \%)$ \\
\hline Female & $382(60 \%)$ & $100(16 \%)$ & $59(9 \%)$ & $149(23 \%)$ & $74(12 \%)$ \\
\hline Total & $639(100 \%)$ & $196(31 \%)$ & $132(21 \%)$ & $193(30 \%)$ & $118(18 \%)$ \\
\hline \multicolumn{6}{|l|}{ Current Status } \\
\hline Freshmen & $139(22 \%)$ & $56(9 \%)$ & $34(5 \%)$ & $39(6 \%)$ & $10(2 \%$ \\
\hline Sophomore & $156(24 \%)$ & $36(6 \%)$ & $28(4 \%)$ & $48(8 \%)$ & $41(6 \%)$ \\
\hline Junior & $191(30 \%)$ & $56(9 \%)$ & $42(7 \%)$ & $60(9 \%)$ & $33(5 \%)$ \\
\hline Senior & $153(24 \%)$ & $45(7 \%)$ & $28(4 \%)$ & $46(7 \%)$ & $34(5 \%)$ \\
\hline \multicolumn{6}{|c|}{ How Interested are the respondents in the following ${ }^{1}\left(\mathbf{H}_{1}\right)$} \\
\hline Environmental Sustainability & 3.3 & 3.2 & 3.4 & 3.5 & 3.3 \\
\hline Human Sustainability & 3.1 & $3.0_{\mathrm{b}}$ & $3.0_{\mathrm{b}}$ & $3.3_{\mathrm{a}}$ & 3.2 \\
\hline Social Sustainability & 3.0 & 3.0 & $2.9_{\mathrm{b}}$ & 3.0 & $3.2_{\mathrm{a}}$ \\
\hline Economic Sustainability & 3.1 & 3.1 & 3.0 & 3.1 & 3.0 \\
\hline
\end{tabular}

\section{Sustainable Business Education - Program Development}

For hypothesis two, there is a significant difference between students from different colleges and their linking socially responsible issues and business practices in educational curricula. Overall, there was a significant difference between "this is essential for business curriculum", "we need to be thoroughly informed", and "employers will look for this" - $p<.05$ (see Table 4). For example, engineering and physical sciences students agreed $(M=3.5)$ that students need to be thoroughly informed significantly more than students in liberal arts and business students $(M$ $=2.9$ and $M=3.2$, respectively).

For hypothesis three, there is a significant difference between students from different colleges and how they would prefer programs in social responsibility business education be offered. When students were asked about programmatic options, $60 \%$ overall would be interested in a sustainable business minor with significant results $\left[\chi^{2}\right.$ $(3)=18.6, p<.01]$. Engineering and physical science students reported higher preferences for this $(72 \%)$ than the other colleges. Seventy-one percent of students overall were interested in elective courses, with significant results $\left[\chi^{2}(3)=23.1, p<.00\right]$. The Colleges of Life Sciences and Agriculture and Liberal Arts students reported this as the highest (74\% and $75 \%$, respectively).

Table 4: Respondents Views On Program Development $(n=639){ }^{1}$

\begin{tabular}{|c|c|c|c|c|c|}
\hline $\begin{array}{l}\text { Linking environmental issues and business } \\
\text { practices in educational curricula }\left(\mathrm{H}_{2}\right)\end{array}$ & Overall & $\begin{array}{c}\text { College of } \\
\text { Business } \\
(\mathbf{n}=196)\end{array}$ & $\begin{array}{c}\text { College of } \\
\text { Engineering } \\
\text { and Physical } \\
\text { Sciences } \\
(n=132)\end{array}$ & $\begin{array}{c}\text { College of } \\
\text { Life } \\
\text { Sciences and } \\
\text { Agriculture } \\
(n=193)\end{array}$ & $\begin{array}{l}\text { College of } \\
\text { Liberal Arts } \\
\quad(n=118)\end{array}$ \\
\hline Interesting but not really relevant & 2.3 & 2.4 & 2.3 & 2.2 & 2.2 \\
\hline We need to be aware of these issues & 3.3 & 3.2 & 3.4 & 3.4 & 3.3 \\
\hline We need to be thoroughly informed & 3.3 & $3.2_{\mathrm{b}}$ & $3.5_{\mathrm{a}}$ & 3.4 & $2.9_{b}$ \\
\hline This is essential for business curriculum & 3.0 & $2.8_{\mathrm{b}}$ & $3.3_{\mathrm{a}}$ & 3.1 & $3.0_{\mathrm{b}}$ \\
\hline $\begin{array}{l}\text { Employers will look for this in my educational } \\
\text { background }\end{array}$ & 2.7 & 2.8 & $3.0_{\mathrm{a}}$ & 2.8 & $2.5_{b}$ \\
\hline \multicolumn{6}{|c|}{$\begin{array}{l}\text { Note: }{ }^{1}=\text { means on a 4-point scale with } 1=\text { strongly disagree; } 4=\text { strongly agree. Means for each individual item compared across } \\
\text { colleges (e.g. Interesting but not really relevant) with different letters significant at } p<.05 \text {. }\end{array}$} \\
\hline \multicolumn{6}{|c|}{$\begin{array}{l}\text { How interested would you be in participating in one or more of the following undergraduate program offerings in sustainable } \\
\text { business? }\left(\mathbf{H}_{\mathbf{3}}\right)\end{array}$} \\
\hline $\begin{array}{l}\text { Sustainable Business as an option (business } \\
\text { students only) }\end{array}$ & $54 \%$ & $54 \%$ & - & - & - \\
\hline Sustainable Business as a minor & $60 \%$ & $57 \%$ & $72 \%$ & $60 \%$ & $53 \%$ \\
\hline Elective courses in Sustainable Business & $71 \%$ & $68 \%$ & $67 \%$ & $74 \%$ & $75 \%$ \\
\hline
\end{tabular}

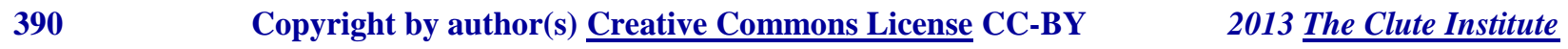




\section{Sustainable Business Education - Curriculum Development}

For hypothesis four, there is a significant difference between students from different colleges in the relevance they place on socially responsible curricula topics. Respondents were asked to prioritize what topics (see Table 5) they saw as most or least relevant to the hospitality management education curriculum. Not all the topics were significant between college groups; however, those that were are highlighted in BOLD. Interestingly, the first five topics relate to entrepreneurship and business practices (see future research topics). The five highest ranked topics reported were clean/renewable energy, green innovation (technology to market), sustainable buildings, green global market development, and energy conservation. For example, overall, $90 \%$ of students selected clean/renewable energy, with significant results $\left[\chi^{2}(3)=20.0, p<.00\right]$, as the most relevant topic to be included in a socially responsible business curriculum. College of Engineering and Physical Science students reported the highest (96\%), followed by Liberal Arts (93\%), Business School (84\%), and Life Sciences (81\%).

Table 5: Respondents Views On Business Curriculum Development $(\mathrm{n}=639)\left(\mathrm{H}_{4}\right)$

\begin{tabular}{|c|c|c|c|c|c|}
\hline $\begin{array}{l}\text { Rate each of these topics you see as being most } \\
\text { or least relevant to undergraduate offerings in } \\
\text { sustainable business education. }\end{array}$ & Overall & $\begin{array}{c}\text { College of } \\
\text { Business } \\
(\mathbf{n}=196)\end{array}$ & $\begin{array}{c}\text { College of } \\
\text { Engineering } \\
\text { and } \\
\text { Physical } \\
\text { Sciences } \\
(n=132)\end{array}$ & $\begin{array}{l}\text { College of } \\
\text { Life } \\
\text { Sciences } \\
\text { and } \\
\text { Agriculture } \\
(\mathbf{n}=193)\end{array}$ & $\begin{array}{c}\text { College of } \\
\text { Liberal } \\
\text { Arts } \\
(\mathbf{n}=118)\end{array}$ \\
\hline Green Innovation (Technology to Market) & $\mathbf{8 8 \%}$ & $89 \%$ & $95 \%$ & $89 \%$ & $\mathbf{7 5 \%}$ \\
\hline Green Global Market Development & $86 \%$ & $91 \%$ & $80 \%$ & $\mathbf{8 8 \%}$ & $79 \%$ \\
\hline Green Entrepreneur & $80 \%$ & $86 \%$ & $90 \%$ & $\mathbf{7 8 \%}$ & $62 \%$ \\
\hline Organizational Management & $71 \%$ & $65 \%$ & $\mathbf{8 5 \%}$ & $79 \%$ & $52 \%$ \\
\hline Product Prototype Design & $69 \%$ & $\mathbf{7 0 \%}$ & $95 \%$ & $66 \%$ & $42 \%$ \\
\hline Clean/Renewable Energy & $90 \%$ & $84 \%$ & $96 \%$ & $81 \%$ & $93 \%$ \\
\hline Sustainable Buildings & $88 \%$ & $85 \%$ & $92 \%$ & $86 \%$ & $92 \%$ \\
\hline Energy Conservation & $86 \%$ & $80 \%$ & $85 \%$ & $91 \%$ & $92 \%$ \\
\hline Sustainable Development Concepts & $84 \%$ & $87 \%$ & $86 \%$ & $79 \%$ & $83 \%$ \\
\hline Environmental Law and Policy & $82 \%$ & $81 \%$ & $79 \%$ & $81 \%$ & $89 \%$ \\
\hline Natural Resource Economics & $79 \%$ & $74 \%$ & $80 \%$ & $85 \%$ & $81 \%$ \\
\hline Green Information Technology Solutions & $78 \%$ & $83 \%$ & $82 \%$ & $71 \%$ & $79 \%$ \\
\hline Green Marketing Research & $\mathbf{7 8 \%}$ & $\mathbf{8 5 \%}$ & $\mathbf{8 3 \%}$ & $69 \%$ & $76 \%$ \\
\hline Creating Strategic Sustainable Business Models & $76 \%$ & $85 \%$ & $77 \%$ & $71 \%$ & $68 \%$ \\
\hline Training and Education & $\mathbf{7 5 \%}$ & $69 \%$ & $82 \%$ & $71 \%$ & $\mathbf{8 3 \%}$ \\
\hline Personal Ethics and Values & $75 \%$ & $74 \%$ & $75 \%$ & $79 \%$ & $94 \%$ \\
\hline Consumer Behavior and Attitudes & $75 \%$ & $75 \%$ & $77 \%$ & $71 \%$ & $78 \%$ \\
\hline Environmental Policy Development & $73 \%$ & $68 \%$ & $68 \%$ & $\mathbf{7 8 \%}$ & $81 \%$ \\
\hline Waste Management & $72 \%$ & $64 \%$ & $\mathbf{8 3 \%}$ & $75 \%$ & $68 \%$ \\
\hline Energy Efficiency Calculations & $71 \%$ & $64 \%$ & $75 \%$ & $73 \%$ & $75 \%$ \\
\hline Product Development & $\mathbf{7 0 \%}$ & $75 \%$ & $81 \%$ & $61 \%$ & $65 \%$ \\
\hline Socially Responsible Investing & $70 \%$ & $74 \%$ & $69 \%$ & $64 \%$ & $70 \%$ \\
\hline Sustainable Business Reporting & $65 \%$ & $75 \%$ & $65 \%$ & $55 \%$ & $65 \%$ \\
\hline Inter-Disciplinary Collaborative Team Building & $62 \%$ & $54 \%$ & $76 \%$ & $59 \%$ & $66 \%$ \\
\hline Environmental Auditing & $61 \%$ & $60 \%$ & $71 \%$ & $57 \%$ & $61 \%$ \\
\hline Corporate Culture Issues & $57 \%$ & $64 \%$ & $42 \%$ & $\mathbf{5 8 \%}$ & $59 \%$ \\
\hline Intellectual Property Management & $53 \%$ & $53 \%$ & $63 \%$ & $47 \%$ & $53 \%$ \\
\hline Purchasing Principles & $53 \%$ & $49 \%$ & $58 \%$ & $54 \%$ & $55 \%$ \\
\hline
\end{tabular}

\section{Sustainable Business Education - Pedagogy}

For hypothesis five, there is a significant difference between students from different colleges and student groups in the pedagogical approaches to teaching social responsibility in business programs. Students were asked how socially responsible concepts and business practices can best be learned. Table 6 shows the results of this assessment. Overall, $76 \%$ of students selected discussion, with significant results $\left[\chi^{2}(3)=12.3, p<.01\right]$ as the best 
way for sustainability concepts and business practices to be learned. Liberal Arts students reported the highest (82\%), followed by Life Sciences (81\%), Business School (70\%), and Engineering (69\%). The least preferred by the students, with significant results $\left[\chi^{2}(3)=15.1, p=.002\right]$, was the use of an individual term paper or project $(26 \%)$. Liberal Arts students reported the highest (39\%), followed by Life Sciences (26\%), Engineering (24\%), and Business School (19\%). The results suggest an overall theme toward pedagogy, with the top three ways student believe this material can be learned based upon experiential learning, such as internships/externships, field trips, and open discussions, rather than the traditional format of lectures and case studies.

Table 6: Respondents Views on Pedagogy $(n=639)\left(H_{5}\right)$

\begin{tabular}{|c|c|c|c|c|c|}
\hline $\begin{array}{c}\text { How Sustainability Concepts and } \\
\text { business practices can best be } \\
\text { learned }\end{array}$ & Overall & $\begin{array}{c}\text { College of } \\
\text { Business } \\
(n=196)\end{array}$ & $\begin{array}{l}\text { College of } \\
\text { Engineering } \\
\text { and Physical } \\
\text { Sciences } \\
(\mathbf{n}=132)\end{array}$ & $\begin{array}{c}\text { College of } \\
\text { Life Sciences } \\
\text { and } \\
\text { Agriculture } \\
(n=193)\end{array}$ & $\begin{array}{l}\text { College of } \\
\text { Liberal Arts } \\
(n=118)\end{array}$ \\
\hline Discussion & $76 \%$ & $70 \%$ & $69 \%$ & $81 \%$ & $82 \%$ \\
\hline Internship/externships & $71 \%$ & $68 \%$ & $71 \%$ & $75 \%$ & $70 \%$ \\
\hline Field trip & $69 \%$ & $70 \%$ & $70 \%$ & $71 \%$ & $64 \%$ \\
\hline Lecture & $59 \%$ & $52 \%$ & $62 \%$ & $62 \%$ & $61 \%$ \\
\hline Guest lecturer/speaker & $58 \%$ & $64 \%$ & $52 \%$ & $58 \%$ & $57 \%$ \\
\hline Experiential learning & $56 \%$ & $54 \%$ & $55 \%$ & $58 \%$ & $57 \%$ \\
\hline Case studies & $54 \%$ & $53 \%$ & $64 \%$ & $50 \%$ & $50 \%$ \\
\hline Small group interactive activities & $45 \%$ & $42 \%$ & $53 \%$ & $39 \%$ & $53 \%$ \\
\hline $\begin{array}{l}\text { Group project with a deliverable to a } \\
\text { business or organization }\end{array}$ & $42 \%$ & $45 \%$ & $48 \%$ & $37 \%$ & $42 \%$ \\
\hline Service learning activities or projects & $42 \%$ & $43 \%$ & $63 \%$ & $44 \%$ & $56 \%$ \\
\hline Group project & $40 \%$ & $38 \%$ & $42 \%$ & $36 \%$ & $48 \%$ \\
\hline Game or simulation & $31 \%$ & $30 \%$ & $31 \%$ & $30 \%$ & $34 \%$ \\
\hline Panel /symposium/forum & $27 \%$ & $19 \%$ & $24 \%$ & $31 \%$ & $38 \%$ \\
\hline Individual term paper or project & $26 \%$ & $19 \%$ & $24 \%$ & $26 \%$ & $39 \%$ \\
\hline
\end{tabular}

\section{IMPLICATIONS FOR BUSINESS EDUCATION}

Higher education is distinctively situated to deal with the challenges of social responsibility by inquiring how society can sustain a quality way of life and provide the same to future generations. Universities are places of learning with the responsibilities to educate future consumers and business leaders. Given the importance of social responsible behavior, it is critical that undergraduate students acquire knowledge of social responsibility concepts and skills to practice within their chosen profession. Today's students need to be prepared to meet both national and international demands of economic, social, and environmental concerns upon graduation. The major contribution of this study was to underscore the differences between the four college groups that influence social responsibility in business curriculum development and to bring to light pedagogical approaches that best satisfy each of the groups surveyed for this study.

Results overall reveal students from the four colleges share a true interest in social responsibility and the study offers path to all business educators to develop a best practices pedagogical approach to social responsibility integration into the educational environment. Although social responsibility in education was viewed as important by each college cohort, it is apparent from the results that there are differences in what topics should be included in the curriculum and how the courses should be taught.

For example, among the four colleges, course content covering the creation of green innovation, green global market development, and clean energy were important topics for the curriculum (Table 5), with examples of the best practices for learning these concepts experiential learning-based, such as internship/externship or field trips (Table 6). 
Making social responsibility in business education meaningful for students and the business community, the interests of the students across all disciplines need to be aligned, which will help improve the environmental, social, and economic literacy of business faculty and students ultimately benefiting industry. One way to bring about this change is for collaboration among educators from different disciplines, industry professionals from varied businesses, as well as students. Yet, issues related to language and research methods can make it hard for stakeholders in different disciplines to work together. Despite increasing interest in and support for interdisciplinary endeavors at universities, few guidelines exist (Deale et al, 2009). For social responsibility to develop interdisciplinary bridges, it is imperative for educators, students, and industry professionals to work together from the initial stages of curriculum formulation and research design.

These are difficult issues and students, as future business managers and leaders, need to debate thoroughly, reflect upon, and evaluate the issues. Then perhaps, as an outcome, they will become socially responsible citizens (Kevany, 2007; Wade, 1999). The learning outcomes must ensure that students can be critical, objective, well informed, and analytical about the subject matter, as well as aware of effective practices and interdisciplinary knowledge of complex issues. Working for a socially responsible future requires more than tinkering with existing systems; it leads people to rethink their approach to business best practices and management. Finally, as Wade (1999) suggested, the curriculum will not be the only influence on students' perceptions of socially responsible issues because many will have been exposed to the influence of the media, political debate, and peer pressure; yet the real vehicle of understanding and change will be the teaching and learning strategies implemented in the higher education curriculum.

\section{LIMITATIONS AND FUTURE RESEARCH}

The study discussed was limited to respondents from a single population at a northeast university; therefore, it is not possible to generalize the findings to all business education students. A larger representative sample from business students might provide even more meaningful results, as would more attention to how social responsibility is treated around the globe.

Although this study has a relatively narrow scope, it does begin the dialog for further work in socially responsible research and curriculum development in business education. The younger generations are a major factor in determining the future and success of businesses, especially the entrepreneurial future, because they represent a force required to steer and manage the rapid changes and they represent the future capacity for economic growth and development (Kroon, De Kirk, \& Dippenaar, 2003). As evidenced in this study, a large number of students view courses in entrepreneurship as important to socially responsible business practices. Thus, future studies should consider how entrepreneurial social responsible education could best be placed in business education with an emphasis on creating an awareness of the option of self-employment, generating interest, and desire for people to learn about the entrepreneurial process and develop the skills necessary to start and run businesses of their own successfully (Kroon, De Kirk, \& Dippenaar, 2003).

Finally, future research should measure industry leaders, educators, administrators, as well as undergraduate students, to fully understand the potential agreement or disagreement each cohort has towards socially responsible business education.

\section{AUTHOR INFORMATION}

Nelson A. Barber, Ph.D., Associate Professor, The Peter T. Paul College of Business and Economics, Department of Hospitality Management, University of New Hampshire, Durham, New Hampshire, 03824, 603-862-3303,. Dr. Barber's research has been published in the Journal of Hospitality and Tourism Research, Cornell Hospitality Quarterly, Journal of Hospitality and Tourism Education, Journal of Consumer Marketing, among others. His MS is from Purdue University and Ph.D. from Texas Tech University. His research focuses on various dimensions of consumer marketing, sustainability, and decision behavior. E-mail: Nelson.barber@unh.edu (Corresponding author) 
Venky Venkatachalam, Ph.D., Professor of Information Systems and Associate Dean of Academic Programs, The Peter T. Paul College of Business and Economics, University of New Hampshire, Durham, New Hampshire, 03824, 603-862-0015. His recent research interests and publications center on leveraging intellectual property, entrepreneurship, innovation, and technology integration. Professor Venkatachalam is currently the project director for a clean energy technology accelerator project (Green Launching Pad), funded by U.S. Department of Energy. Dr. Venkatachalam created the Enterprise Integration Research Center to assist high-tech companies in obtaining funding for intellectual property, including patents, trademarks, and copyrights. E-mail: venky.venkatachalam@.unh.edu

\section{REFERENCES}

1. AACSB (2012). B-Schools and sustainability. Association to Advance Colleges and Schools of Business. Available at http://www.aacsb.edu/sustainability/index.html (accessed June 10, 2012).

2. AASHE (2012). 2011 Higher Education Sustainability Review. Association for the Advancement of Sustainability in Higher Education. Available at http://www.aashe.org/files/private/2011 he review_final.pdf (accessed August 2, 2012).

3. Aber, J., Kelly, T. \& Malory, B. (2009). The sustainable learning community: One University's Journey to the Future. University of New Hampshire Press: Durham, New Hampshire

4. Alvarez, A., \& Rogers, J. (2006). Going "out there": Learning about sustainability in place. International Journal of Sustainability in Higher Education, 7(2), 176-188.

5. Barth, M. \& Timm, J.M. (2011). Higher Education for Sustainable Development: Students' Perspectives on an Innovative Approach to Educational Change. Journal of Social Science, 7, 13-23.

6. Barber, N., Deale, C. and Goodman, R. (2011). Sustainability in the Hospitality Business Curriculum: A Pilot Study of Perspectives from Three Groups of Stakeholders. Journal of Hospitality and Tourism Education, 23(1), 6-17

7. Blundel, R.K., Spence, L.J., \& Zerbinati, S. (2010). 'Entrepreneurial social responsibility: scoping the territory.' In: Spence, L.J. and Painter-Morland, M. (eds.) Ethics in Small and Medium Sized Enterprises: A global commentary, Dordrecht, NL, Springer.

8. Bradbury, H. (2003). Sustaining inner and outer worlds: A whole-systems approach to developing sustainable business practices in management. Journal of Management Education, 27(2), 172-187.

9. Business for Social Responsibility (2006). Taking the temperature of CSR leaders. Available at: www.bsr.org/Meta/BSRleaders survey.pdf (accessed December 2, 2012).

10. Business in the Community (2005). Available at: www.bitc.org.uk/resources/jargon_buster/cr.html (accessed October 15, 2012).

11. Christensen, L. J., Peirce, E. Hartman, L. P., Hoffman, W. M., \& Carrier, J. (2007). Ethics, CSR, and sustainability education in the Financial Times Top 50 Global Business Schools: Baseline data and future research directions. Journal of Business Ethics, 73, 347-368.

12. Deale, C., Nichols, J., \& Jacques, P. (2009). A Descriptive Study of Sustainability Education in the Hospitality Curriculum. Journal of Hospitality \& Tourism Education, 21 (4), 34-42.

13. Dow Jones Sustainability Index (2012). Corporate Sustainability. Available at http://www.sustainabilityindex.com/sustainability-assessment/corporate-sustainability.jsp , (accessed January 19, 2013).

14. Down, L. (2006). Addressing the challenges of mainstreaming education for sustainable development in higher education. International Journal of Sustainability in Higher Education, 7(4), 390-399.

15. Eber, S. (2002). Integrating sustainability into the undergraduate curriculum: Leisure and Tourism. Guidelines published by University of North London and the Association of Tourism in Higher Education. Available at http://www.athe.org.uk/publications/guidelines_10.pdf , (accessed January 22, 2013).

16. Elkington, J. (1998). Partnerships from cannibals with forks: The triple bottom line of 21st-century business. Environmental Quality Management, 8(1), 37-51.

17. Fien, J. (2002). Advancing sustainability in higher education. International Journal of Sustainability in Higher Education, 3(3), 243-253.

18. Haski-Leventhal, D. (2012). Corporate Responsibility and Responsible Management Education in the Eyes of MBA Students: The MGSM - PRME MBA Global Student Survey. Available at http://www.unglobalcompact.org/docs/issues_doc/PRME/PRME_MBA_Student_Study.pdf, (accessed December 10, 2012). 
19. Holcomb, J., Upchurch, R. \& Okumus, F. (2007). Corporate social responsibility: what are top hotel companies reporting? International Journal of Contemporary Hospitality Management, 19(6), 461 - 475.

20. IISD (2004), "Perceptions and Definitions of Social Responsibility", Available at http://inni.pacinst.org/inni/corporate_social_responsibility/standards_definitions.pdf, (accessed October 15, 2012).

21. Jurowski, C. \& Liburd, J. (2001) A multi-cultural and multi-disciplinary approach to integrating the principles of sustainable development into human resource management curricula in hospitality and tourism. Journal of Hospitality and Tourism Education, 13 (5), 36-50.

22. Karna, J., Hansen, E., \& Juslin, H. (2003). Social responsibility in environmental marketing planning. European Journal of Marketing, 37(5), 848 - 871.

23. Kevany, K. D. (2007). Building the requisite capacity for stewardship and sustainable development. International Journal of Sustainability in Higher Education, 8(2), 107-122.

24. Kroon, J., De Kirk, S \& Dippenaar, A. (2003). Developing the next generation of potential entrepreneurs: cooperation between schools and businesses? South African Journal of Education, 23(4), 319-322.

25. Lourdel, N., Gondran, N., Laforest, V., Debray, B., \& Brodhag, C., (2007). Sustainable development cognitive map: a new method of evaluating student understanding, International Journal of Sustainability in Higher Education, 8(2), 170-182.

26. Luchs, M.G. \& Mooradian, T.A. (2012). Sex, Personality, and Sustainable Consumer Behaviour: Elucidating the Gender Effect. Journal of Consumer Policy, 35, 127-144.

27. Maignan, I., Ferrell, O.C. \& Ferrell, L. (2005). A stakeholder model for implementing social responsibility in marketing. European Journal of Marketing, 39 (9), 956 - 977.

28. Miller Jr., T. (2005). Living in the environment: Principles, connections, and solutions. Brooks/ColeThomson Learning, Inc.

29. Moore, J. (2005). Seven recommendations for creating sustainability education at the university level. International Journal of Sustainability in Higher Education, 6(4), 326-399.

30. Net Impact (2010). Undergraduate perspectives: The business of changing the world, Net Impact. Available at http://netimpact.org/docs/publications-docs/NetImpact_UndergradPerespectives_2010.pdf, (accessed June 5, 2012).

31. Nicholson, C. Y. \& DeMoss, M. (2009). Teaching ethics and social responsibility: An evaluation of undergraduate business education at the discipline level. Journal of Education for Business, 84(4), 213-218.

32. Odell, A. M. (2008). Transparent Supply Chain Sends A Clear Message. SRI World Group, Inc. Available at http://www.socialfunds.com/news/save.cgi?sfArticleId=2496, (accessed February 7, 2013).

33. Pesonen, H. (2003). Challenges Of Integrating Environmental Sustainability Issues Into Business School Curriculum: A Case Study From The University Of Jyväskylä, Finland. Journal of Management Education, 27, 158.

34. Porter, M. \& Kramer, M. (2006). Strategy and society: the link between competitive advantage and corporate social responsibility. Harvard Business Review, 84(12), 78-89.

35. Posch, A., \& Steiner, G. (2006). Integrating research and teaching on innovation for sustainable development. International Journal of Sustainability in Higher Education, 7(3), 243-253.

36. Roome, N. (2005). Teaching sustainability in a global MBA: insights from the OneMBA. Business Strategy and the Environment, 14, 160-71.

37. Rusinko, C. A. (2010). Integrating sustainability in higher education: A generic matrix. International Journal of Sustainability in Higher Education, 11(3), 250-259.

38. Sammalisto, K., \& Lindhqvist, T. (2008). Integration of sustainability in higher education: A study with international perspectives. Innovative Higher Education, 32(4), 221-233.

39. Savitz A.W \& Weber K. (2007). The sustainability sweet spot. Environmental Quality Management, 17(2), $17-28$.

40. Singhapakdi, A., Karande, K., Rao, C. P., \& Vitell, S.J. (2001). How important are ethics and social responsibility? - A multinational study of marketing professionals. European Journal of Marketing, 35(1), 133-153.

41. Stubbs, W. \& Schapper, J. (2011).Two approaches to curriculum development for educating for sustainability and CSR. International Journal of Sustainability in Higher Education, 12(3), 259 - 268. 
42. Swanger, N., Benson, L. \& Paxson, C. Innovative ecotourism projects: impact on environmental attitudes in introductory hospitality courses. Available at http://pc.parnu.ee/ htooman/EuroChrie/Welcome\%20to\%20EuroCHRIE\%20Leeds\%202007/EuroCHRIE \%20Leeds\%20Conference\%20Preceedings/Full\%20Papers/Paxson,\%20Chris.pdf , (accessed January 9, 2013).

43. Tesone, D.V. (2004). Development of a sustainable tourism hospitality human resources management module: a template for teaching sustainability across the curriculum. International Journal of Hospitality Management, 23(3), 207-237.

44. Wade, J. (1999). Students as environmental change agents. International Journal of Contemporary Hospitality Management, 1(1/5), 251 - 255

45. Wright, J. (2003). Introducing sustainability into the architecture curriculum in the United States. International Journal of Sustainability in Higher Education, 4(2), 100-105.

46. Yencken, D. \&Wilkinson, D. (2000). Resetting the compass: Australia's journey towards sustainability, Melbourne: CSIRO Publishing. 